\title{
Social dreaming and ecocentric ethics: sources of non-rational insight in the face of climate change catastrophe
}

\author{
Jonathan Gosling and Peter Case
}

\begin{abstract}
The article considers the role of dreams as social, rather than individual, phenomena and suggests that as such they may serve as resources for 'future imaginings' with respect to potentially devastating consequences of climate change (and other transgressions of planetary boundaries). Adopting a socio-analytical perspective, it contemplates the possibility of a societal level 'cosmology episode' caused by catastrophic climate change; a critical point of rupture in the meaning-making process which leaves local rationalities in ruin. Drawing on a 'representative anecdote', the article finds allegorical parallels between the cultural collapse of a traditional indigenous culture and the impending threat of ecocrisis currently facing humanity. The possibilities of seeing and imagining offered by collective forms of dreaming are explored alongside development of a non-anthropocentric ethics. Our focus is on ways of sensing, thinking and talking about climate change that are less dependent on a rational conscious subject. The article thus enquires into what cultural means or resources might be available to (post)modern western societies that, like the shamanic dream-vision of certain traditional cultures, might enable them to draw on non-anthropocentric sensibilities and organize responses to an impending cultural crisis. We conclude by offering Gordon Lawrence's social dreaming matrix as one possible medium through which to imagine and see beyond climate change catastrophe.
\end{abstract}

\section{Keywords}

catastrophe, climate change, social dreaming, socio-analysis, cosmology episode, ecocentric ethics 


\section{Introduction}

It is possible that contemporary western societies will adapt to the changes arising from climate change, biodiversity loss, water shortages and so forth, and that we will be able to preserve the ways of life we value by incremental changes, ingenuity and effective global governance (Ridley, 2011; Berkes et al 2000; Berkes \& Turner, 2006; Gilding and Randers, 2010; Rockström et al. 2009; Whiteman et al. 2012). But it is also possible that western ways of life, the things that count in (post)modern societies, will not be preserved. The balance of probability is contested, of course. The optimism and ignorance of climate change deniers is challenged by the more apocalyptic and dystopian accounts of other voices (see, for example, Hansen, 2011; Lomborg, 2007; Lovelock, 2007; Urry, 2008). To speak of 'adaptation' implies a relatively simple swapping of one practice for another. If the winters are no longer so cold humanity will adapt by growing more tropical crops; if sea waters rise people will move to higher ground. If 20 million climate refugees move from North Africa to Northern Europe, we will all shift along and snuggle up. But what if humanity faces a crisis of abysmal, catastrophic proportions? How should such a possibility be approached and what forms of organizational practices might be engaged? Assuming the direst predictions of climate science are correct and the planet is, indeed, facing climate catastrophe, it becomes imperative for modern western societies - and those peoples who aspire to emulate their lifestyles - to imagine this prospect. Such imaginings must be a prelude to any form of action taken to avert or prepare for the consequences ahead as humanity sits precariously on the edge of the abyss.

The forms of imagination we explore in this article mark a radical challenge to the predominantly rational and techno-scientific hegemony of approaches to organization that presently populate mainstream management and organization studies. We will suggest that dreams, unorganized but nonetheless meaningful, constitute a valuable resource for those confronted with such unprecedented challenges. By introducing examples of oracular interpretations and a 'social dreaming matrix', we will consider ways of connecting with these experiences such that they might be drawn upon as collective rather than individual resources. We use a 'representative anecdote' (Burke, 1941) to explore the historically specific experience of an indigenous people faced with cultural collapse, and draw inspiration from some of their coping strategies. This enables us to develop a counter-flow in theorization that questions received western organizational wisdom and leads us to contemplate the non-rational possibilities of imagination afforded by dreams.

In his book Radical Hope: Ethics in the Face of Cultural Devastation, Lear (2006) undertakes a close historical examination of an American indigenous people's preparation for, and response to, cultural catastrophe. When faced with inconceivable change and a present for which they had no concepts, the Apsáalooke people (referred to throughout this article by their western designation the 'Crow') in the nineteenth century were apparently guided by certain dream-images. These were dreamt and interpreted - at least sometimes (Benedict, 1922) - in a manner that provided a reference to relevant virtues of courage and what we might take in 
contemporary parlance to be strategic learning and organization in the face of an imminent threat. The term strategic is invoked here in a very specific sense: it is not referring to long term planning (clearly impossible in situations of collapse); rather we refer to strategic learning as an attitude of alertness and readiness, as described, for example, by Chia and Holt in Strategy Without Design (2011). Specifically, it is an attitude in which the agency of the leader, manager or principal actor is limited, conditional and dependent. Lear's account emphasises the significant leadership role of the Crow Chief, Plenty Coups, in responding to cultural catastrophe. We find value in Lear's admittedly westernized interpretation (and possibly interpolation) of the Crow story insofar as it prompts us to consider non-rational aspects of future imaginings and responsive actions. In this article, we follow Chia and Holt (2011) in doubting the efficacy of individual or even collective intent, to explore the potential for a non-anthropocentric ethics that could inform ways of imagining a future which, at present, remains relatively obscure.

Organisation scholars have often criticised the explanatory power of theories that rely on individual human ethics, decisions and actions. Alternatives include collective processes of sense-making (Weick, 1979); social identity (Tajfel and Turner, 1986; Haslam et al, 2008); corporate culture (Schein, 2004); and social embeddedness (Uzzi, 1999). However all these assume a dualistic separation between humans and nature. Even if one allows for the social construction of this separation (Latour, 1993), it emphasises the social rather than ecological. Whiteman and Cooper (2000) propose 'ecological embeddedness' in recognition of the extent to which indigenous peoples are 'on the land and learn[s] from the land in an experiential way' (2000: 1267). Whiteman and Cooper's argument focuses on how ecological embeddedness affects managers' practices with respect to ecological sustainability; and their adaptability to crises through ecological sensemaking and sensegiving (Whiteman and Cooper, 2011). Our interest in this construct is how it might enable us to identify, appreciate and mobilise new resources for dealing with a breakdown in cultural norms; that is, when existing practices, based on anthropocentric assumptions, have proven unsustainable.

The principle conceit of this article, then, is to take an account of the cultural catastrophe endured - and, most importantly, survived - by a specific indigenous nation, and to treat this as an allegory for both the present and future faced by humanity. Here we follow Constanza et al. (2007) and Diamond (2005) in arguing that there are practical lessons and, indeed, 'solutions' that can be gleaned both from historical experiences of ecological and cultural collapse and collective organizational responses to such catastrophic events ${ }^{1}$. Although separated markedly by time, history and circumstance, we contend that there are, indeed, many parallels between the representative anecdote we have selected and contemporary ecocrisis: the prospect of ecosystem collapse which threatens not only western and westernizing nations but those non-western peoples and non-human species that inhabit this fragile planet. Despite the cultural chasm that obviously exists between a nomadic people of the North American plains and mass industrialized and postindustrial societies of the contemporary west, there are certain patterns of human virtue and ethics which make this unlikely comparison highly fecund. It is a 
comparison that offers a kind of moral litmus test through which we might better assess and understand the complexity of the western and westernizing condition.

We explicitly position our use of allegory within an 'American Indian' (Vizenor, 1998) postcolonial critique of Western scientific narrative (Cajete, 2000; Warrior, 1995) and methodology (Jack and Westwood, 2009; Smith, 2000). However, in so doing we should nonetheless emphasise that we are not attempting to make any form of anthropological contribution in this article or, indeed, claim any novel insight into the specific culture we wish to learn from. Rather, we are employing a story about another place and time as a means of suggesting new ways of seeing some aspects of our own contemporary situation. Ours is, by necessity, a speculative exercise; an attempt to think through cultural and ethical logics that we have yet to encounter. It is, in temporal terms, something akin to a reverse thought experiment in counterfactual history; one in which we try to work through the 'what ifs' of prospective futures in which ecocrisis has translated, at worst, into geopolitical meltdown or, at the very least, significant modification of our current ways of life. However speculative, we hope that the reasoning and 'discoveries' yielded by this thought experiment prove to be of value to the scholarly community and beyond.

\section{Imagining climate change catastrophe}

The aim is to establish what we might legitimately hope at a time when the sense of purpose and meaning that has been bequeathed to us by our culture has collapsed (Lear, 2006: 104, original emphasis).

Many scholars from assorted disciplines - climate science, economics, biology, sociology, anthropology - are convinced that the current path of economic growth and consumerism in the west and westernizing nations is entirely unsustainable. These accounts include consideration of the effects of populations growth, affluence and material production on $\mathrm{CO}_{2}$ emissions and climate change (Behrensa et al., 2007; Intergovernmental Panel on Climate Change, 2007; Dietz and Rosa, 1997; Herrmann and Hauschild, 2009; Monbiot, 2007; Myers and Kent, 2003; Raupach et al., 2007), as well as assessment of alternative economic analyses of the effects of climate change (Stern, 2007; Jackson, 2009; Collier, 2010). Some analyses carry doom laden predictions (Hansen, 2011; Heinberg, 2005; Lovelock, 2007; Urry, 2008) and the potentially catastrophic effects of reaching ecological 'tipping points' (Lanchester, 2007; Lenton, et al., 2008), but even the more optimistic writers (Collier, 2010; Jackson, 2009; Monbiot, 2007) countenance a great deal of local and geopolitical turmoil if current collective behaviour patterns with respect to energy, water, mineral usage, destruction of biodiversity and so forth do not radically change in the near future.

If worst case scenarios are considered, then western cultures face prospective obliteration as social, economic and political systems breakdown under the strains imposed by unsustainable world population growth, economic and political migration and corresponding resource scarcity. Even accepting that governments are 
able successfully to negotiate binding international agreements which are acceptable to their polities and which halt or, where necessary, reverse the most damaging excesses of current economic growth trajectories, the resulting changes in policy will necessitate significant changes in lifestyle (Raskin et al., 2002). Western societies will simply have to come to terms, collectively, with ways of living which differ radically from those that they have become accustomed to. This will translate into having to address both absolute and relative levels of affluence.

Whether humanity is destined to encounter a series of cultural catastrophes or more moderate and 'managed' transitions (Raskin et al., 2002), there are ethical lessons that can be taken from earlier experience to inform our own dilemmas (Costanza et al., 2007a, 2007b; Diamond, 2005). Lear, for example, distils from the story of the Crow themes of courage and 'radical hope' which speak to 'a good for which those who have the hope as yet lack the appropriate concepts with which to understand it' (2006: 103). Our contention is that there are already signals within western societies of looming ecocrisis and prospective disaster; conditions which our current cultural apparatus - however complex - ill equips us to cope with. As Lear concludes on the basis of his westernized interpretation of the Crow experience, cultures do not routinely educate their populations or prepare them for the possibility of devastation. It is effectively a 'blind spot' of any culture. As he asserts:

By and large a culture will not teach its young: 'These are ways in which you can succeed, and these are ways in which you will fail; these are dangers you might face and here are opportunities; these acts are shameful, and these are worthy of honor [sic] - and, oh yes, one more thing, this entire structure of evaluating the world might cease to make sense.' (2006: 83).

Such education and preparation, however counter-intuitive, is not impossible to conceive. The main normative point we want to make here is that it is just such educational priorities which we in the west should be considering as we face the prospect of deepening ecocrisis and its likely bio-physical and socio-economic consequences. In effect, we need to find ways of imagining cultural catastrophe now if the worst excesses of what may be in prospect for western civilization - and those peoples and species also implicated by western-induced ecocrisis - are to be mitigated. The signals of crisis are already present and it could also be argued that there are extant cultural resources that could be employed to ponder alternative visions. As we indicate below, there are many voices articulating the nature and extent of the crisis as well as those offering possible courses of action.

\section{A new ethics?}

Patrick Curry contends that ethical systems which developed in the west originating in Ancient Greek and Judeo-Christian thought and modified by the rationalities of the Enlightenment - have unintentionally brought about an ethical pathology (Curry, 2006). Ecological crisis is the direct consequence, he maintains, of trajectories of ethically informed action and the pursuit of what our civilization considers to be the 'good'. The basic problem is that what has intuitively made sense 
as the good, namely, material possession and consumerism in manifold forms are not universally good when looked from a non-anthropocentric or planetary perspective. Curry argues for a radical reform of the ethical affinities that lead us to ignore the consequences of our collective behaviour patterns, aspirations and lifestyles on planetary resources and other species. It is not that ethical principles associated with virtue ethics, deontology or utilitarianism have to be abandoned altogether, but rather that they need to be adapted to a new context which is sensitive to and compatible with 'ecocentric' ethics. In other words, the ethical apparatus we currently turn to by way of justifying action and motivating contested notions of the good all place human interests at the centre of the equation. This anthropocentrism, Curry maintains - along with others (Lovelock, 2007; Naess, 1989; Sylvan and Bennett, 1994) - is not only having devastating effects on the environment in terms of anthropogenic climate change, reduction in biodiversity, resource depletions and so forth, it also carries a major sting in the tail for the human race itself.

Ecocentric - literally earth-centred - ethics seeks to displace the human with respect to ethical decision making. It has advantages over other forms of nonanthropocentric ethics, such as biocentric ethics (which privilege animal and other organic life), in that it includes both animate and non-living (mineral) entities in a holistic field of action. According to Curry, ecocentric ethics is manifest in a variety of contemporary intellectual and activist social movements associated with, for example, Gaia Theory, Deep Ecology, Deep Green Theory, Left Biocentrism and Ecofeminism. This is not the place to enter into a detailed discussion of the differences in complexion between these various alternatives, rather, for the purposes of our argument, it will suffice to consider the basic criteria which make for an ecocentric ethics. Curry (2006: 63-4, original emphases) identifies three conditions that have to be met by truly ecocentric ethical thinking: (1) ecocentric ethics 'must be able to recognize the value, and therefore support the ethical defence, of the integrity of species and of ecosystemic places, as well as human and non-human organisms'; (2) must 'allow for conflicts between the interests of human and non-human nature', and (3) 'allow human interests, on occasion, to lose'.

These criteria pose a major challenge for conventional ethical thinking and, if accepted as a new basis for choices directed toward 'the good', would necessitate a great deal of adjustment. Committing to these kinds of principles necessitates giving up current preoccupation with economic growth measured by outmoded notions, in ecocentric terms, such as, Gross Domestic Product (Jackson, 2009: 179) and to seek more sophisticated means of evaluating the impact of human economic activity on the environment. One example of the latter is the Gross Domestic Happiness indicator deployed in Bhutan (McDonald, 2005) and now being considered in the UK. Other examples taken from the field of environmental economics would include the valuation of ecosystem services (Costanza and Folke, 1997) and the operation of 'marginal disutility' and 'uneconomic growth' (Daly and Farley, 2004: 231). And these are by no means radical propositions, for they depend on attaching monetary value to nature; conceiving nature as a resource with extrinsic value but ignoring possible intrinsic or spiritual value. Whether radical or not, alternative measures of 
'prosperity without growth' entail shifting the social logic of consumerism on which economic aspirations are premised and coming to terms with reduced material circumstances.

It is in the reassessment of notions of 'the good' and strategic organizational responses to cultural crisis that we think there is much to be learned from the experience of indigenous, 'ecologically embedded' peoples. Here we refer to a representative anecdote (Burke, 1941), not as an exemplar of directly transferable practices from one culture to another, but, rather, as a means to suggest alternative lines of enquiry. In other words, we treat the following anecdote as a suggestive story. We are explicitly not seeking to provide a comprehensive account of the traditional society selected nor making claims about the anthropological significance of the particular practices we describe.

\section{Representative anecdote: the Crow Indians' crisis of cultural logic}

Following waves of colonization on the part of Europeans over the past five hundred years, stories of the demise of the multiple and variegated ways of life of peoples' indigenous to the Americas is disturbing and distressing in ways that it is impossible properly to register. Against this horrific historical backdrop, however, Lear (2006) offers an account of how the Crow nation, under the leadership of one of its chiefs, Plenty Coups ${ }^{2}$, adapted to the seeming inevitability of their historical circumstance. Lear is a US philosopher and psychoanalyst who, through a western-centric reading of the story, positions Plenty Coups as a figure who helped the Crow people reinvent themselves culturally and thereby survive white invasion and territorial encroachment. Lear's point of departure is a documented encounter between a white American trapper, hunter cowboy and writer, Frank B. Linderman and Plenty Coups. From a series of interviews, Linderman - a contemporary and self-declared friend of Plenty Coups - creates a record of the Crow's history during the nineteenth and early twentieth century from Plenty Coup's perspective. This recorded narrative, which has been criticized for being overly romantic and ethnocentric (Smith, 2000), provides stories of nomadic community life prior to white intrusion and the gradual demise of their culture as territories are appropriated and the Crow nation finally confined to a reservation (Linderman, 1930). What connects particularly with Lear's philosophical sensibilities in these accounts is a refusal on the part of Plenty Coups to narrate anything of his or the Crow experience once they finally give up their nomadic way of life:

Plenty Coups refused to speak of his life after the passing of the buffalo, so that his story seems to have been broken off, leaving many years unaccounted for. 'I have not told you half of what happened when I was young,' he said, when urged to go on. 'I can think back and tell you much more of war and horse-stealing. But when the buffalo went away the hearts of my people fell to the ground, and they could not lift them up again. After this nothing happened. There was little singing anywhere. Besides,' he added sorrowfully, 'you know that part of my life as well as I do. You saw what 
happened to us when the buffalo went away' (Linderman, 1930: 311, quoted in Lear, 2006: 3, added emphases).

What perplexes Lear is the philosophical status and anthropological implications of Plenty Coups' assertion, 'after this nothing happened', and it is an exploration of this conundrum that occupies the entirety of his account. He discounts simplistic explanations rooted in psychological reductionism. For example, the idea that after being confined to the reservation the Crow Indians became depressed and life ceased to matter to them is too superficial an explanation. Whilst it has the merit of making sense to us and is plausible - Plenty Coups could have been depressed and, moreover, could have been giving voice to a wider malaise that afflicted his people Lear argues that there is contrary evidence. For instance, Plenty Coups seemed to take up farming life enthusiastically and was politically active in lobbying the US government to prevent a bill that would entail further appropriation of Crow land. In 1921, at a ceremony in Arlington, he was invited to represent the American-Indians who died during the First World War. His active engagement in a rounded domestic, social and political life, argues Lear, does not speak to the symptoms of depression. Hence another, more nuanced, psychoanalytical interpretation of the phrase 'after this nothing happened' is required. His contention is that what motivated Plenty Coups' refusal to narrate events 'after the buffalo went away' was his experience of an end of history; not in a Hegelian sense of fulfilment of historical purpose, but literally, an end of historical meaning. As he claims, 'the Crow ran out of whens' (2006: 41, original emphasis), and through the loss of cultural signification had to live with a 'real loss of a point of view' (2006: 32, original emphases).

\section{The role of the dream-vision in Crow life}

Before we consider in detail ways in which this story of cultural catastrophe connects ethically with problems faced by western societies, there is one element that needs introduction; namely, the role played by dream-vision in the development of what we might, in contemporary western parlance, think of as the Crow people's strategies of adaptation to their radically changed circumstances. The part played by prescient dreams and visions within traditional societies is widely documented in anthropological and psychoanalytic literature (see, for example, Adlam and Holyoak, 2005; Atkinson, 1992; Benedict, 1922; Campbell, 1973; Duerr, 1985; Goulet, 1998; Versluis, 1993). This record seems to suggest that, in a historically and culturally diverse number of instances, dreams and visions form part of an explicit social matrix. Unlike the modern psychoanalytic traditions of the west that place emphasis on the individual significance of dreams with respect to personal mental health, traditional societies invest in both individual and collective meaning of dreams. Moreover, such dreams and visions form part of cosmologies in which an external spirit world and magic is taken to be of real consequence, especially when it comes to matters of prophecy and oracular content. Such cosmological possibilities are, of course, generally considered anathema by western sciences which place emphasis on rational-material structures of explanation ${ }^{3}$. 
Dreaming and dream-vision formed an important ingredient of Crow communal life, as it did for other plains Indians ${ }^{4}$ - though in very diverse ways. They had their own cosmology of dreams, ranging from those that carried no significance, through dreams which assisted with practical tasks such as hunting buffalo, to dreams with powerful 'medicine' which were interpreted as foretelling events (Lear, 2006, p.67). Dream-visions were of the latter category and typically involved boys or young men taking a sweat-bath and fasting before being sent out to a remote place where they were to plead for the Great Spirit to grant a dream (Cf. Campbell, 1973: 211-12). The dream seeker would ask the Spirit to take pity on him. This supplication often entailed some degree of self-mutilation; typically cutting off the top of a finger (though there is some evidence that 'self-torture' was a $19^{\text {th }}$ Century innovation across several tribes, possibly a response to European invasion (Benedict, 1922). If a dream-vision was granted, the individual would return to the tribe and a formal council of elders would be called to hear and interpret the dream. At the age of nine, in 1855 or 1856, according to Linderman (1930) Plenty Coups undertook just such a sojourn. The dream-vision that resulted was rich in symbolism and came to inform the Crow people's response to their longer term fate at the hands of the whites. Space prohibits a detailed recounting of the dream imagery (see Lear, 2006: 69-72), but suffice to say that it included many detailed prophetic elements, such as: the complete disappearance of buffalo and their replacement by 'spotted buffalo' (which had longer tails and weaker calls than the familiar plains buffalo); a traumatic storm which deforested Crow land and left only one tree - the lodge of the Chickadee standing; and, a magical figure - the chickadee-person - who urged Plenty Coups to develop his mind in as much measure as his body.

On hearing the dream, one of the elders, Yellow Bear, offered an interpretation as follows:

He [Plenty Coups] has been told that in his lifetime the buffalo will go away forever... and that in their place on the plains will come the bulls and cows and calves of the white man. I have myself seen these Spotted-buffalo drawing loads of the white man's goods... The dream of Plenty-coups [sic] means that the white man will take and hold this country and that their Spotted-buffalo will cover the plains. He was told to think for himself, to listen, to learn to avoid disaster by the experiences of others. He was advised to develop his body but not to forget his mind. The meaning of this dream is plain to me. I see its warning. The tribes who have fought the white man have all been beaten, wiped out. By listening as the Chickadee listens we may escape this and keep our lands (Linderman, 1962: 73, quoted in Lear, 2006: 72).

Whilst leaving open the space for this dream-vision to make sense as prophecy in terms of the Crow's spiritual cosmology, Lear favours a more traditional Freudian explanation of the manifest dream content ${ }^{5}$. For Lear, this dream speaks to a form of collective anxiety, various causes of which were distributed within the community at the time (mid-nineteenth century) of its occurrence. Sources of Crow anxiety would have included having to cope with: (a) the serious depletion in herds of buffalo 
caused by white trapping and trading ${ }^{6}$; (b) the effects of smallpox epidemics; and, (c) increased competition with Sioux and Blackfeet tribes over diminishing territory as white settlement encroached ever further on their lands. Within this context, Plenty Coups' dream could be interpreted 'as a response to a communal sense of anxiety, as well as an indication of how they moved forward in the face of anxiety' (Lear, 2006: 77).

Working with the 'wisdom of the Chickadee', however, under Plenty Coups' leadership, the Crow did manage to negotiate many concessions from the US government and, by deliberately pursuing a path of collaboration rather than confrontation with its military, succeeded in coming off better, overall, than those tribes which took a more aggressive stance. It was not that Yellow Bears' interpretation of 'holding on to the tribal lands' turned out to mean having the freedom to roam the plains and preserve the traditional lifestyle. The traditions were all but obliterated once the Crow were confined to a two million acre reservation, had to farm individually parcelled allocations of land and endure a humiliating system of rationing. But they were able to adapt and survive where other tribes were physically annihilated.

\section{The Crow story as allegory}

From this account of the Crow way of life, their adaptive strategies and their surviving what effectively amounted to a cultural catastrophe, we draw a parallel with the precarious position occupied by contemporary societies facing the effects of anthropogenic climate change and impending ecocrisis. The Crow story is suggestive, we contend, of social resources that might be mobilized in order to provoke imaginative ways of seeing through to the other side of climate catastrophe.

If some of the more extreme scenarios of ecocrisis turn out to be accurate, however, we in the west will find ourselves in a 'cosmology episode' writ large (Weick, 1993: 633); a catastrophic point at which our own meaning systems are stressed to the point of breakdown. There will no longer be the supporting conditions - economic, social, political - for us to enjoy ever increasing levels of affluence and material prosperity. Just as the Crow had to work through individual and collective crises in meaning as their traditional lifestyle collapsed, so we, too, will have to face and cope with a radically different way of living.

Contemporary discourses around 'sustainability' and 'the green economy' (UNEP, 2011) mobilize images of harmonious relations between human industry and nature in ideas such as 'the circular economy', in which waste is endlessly recycled in a pollution free, resources-neutral perfect balance (McDonough \& Braungart, 2002; Stahel, 2010; Macarthur, 2012). A magical transformation to these utopias is not essential to their nature, for a circular economy does not in itself imply a radical cleansing of linear thinking. There is, however, a strong implication that transgressing planetary 'limits to growth' (Meadows et al, 2004) will incur at least a 
'great disruption' (Gilding, 2011) to the ways we live. Many authors predict far more disastrous outcomes (e.g., Lovelock, 2007; Dyer, 2008).

Of course, apocalyptic accounts inevitably serve the political interests of some classes of people - it is clear how this worked in soviet Russia and Nazi Germany; and, for example, Islamic theologies of the end of days are manifest in contemporary politics in Afghanistan, Egypt and elsewhere. It is not surprising, therefore, that climate-change deniers, mainly in the USA, frequently decry the supposed political interests motivating predictions of ecological catastrophe (paradoxically, also lionizing 'the American way of life').

However, accounts of a coming apocalypse need not be read literally as predictions of the imminent future, but rather as referring to another kind of reality, a parallel world of experience in which we live, but not dominated by waking rational consciousness. In this sense, the apocalyptic world may not be something we go through once-and-for-all, but rather something that accompanies us through catastrophe ${ }^{7}$. We are, in other words, always on the borderline of the apocalyptic, and when catastrophe strikes, destroying the order that we have become used to and by which we define ourselves, the apocalypse appears more potent, present and real (Cohn, 1957).

Psychoanalytic literature on disaster, particularly Segal (1987) and Stein (2004), helps in conceptualizing and anticipating the kind of catastrophic moment we have in mind. Analysing the cases of the Mann Gulch and Three Mile Island disasters, Stein identifies three broad phases of events that lead to organizational catastrophe: an 'incubation period', 'critical period' and 'aftermath' (Stein, 2004: 1244). He concludes that 'anxiety toleration' within social technical systems plays a significant role in determining whether or not signals of crisis are acted upon successfully. The point is that collective organizational forms often contain embedded anxiety defences, which mitigate against effective registering of the signs of crisis present within a system at the 'trigger point'. Where such anxiety defences are well established they can easily result in a false illusion of control and manageability on the part of key decision-makers within the organizational system. For example, meter readings in a nuclear power plant, are explained away with false confidence as being the result of faulty instrumentation or their significance downplayed. As Stein frames it:

[I]n general, a helpful response to the critical period is likely to be one that steers a course between the absence of anxiety (denial) and excessive anxiety (panic). While we should have considerable sympathy for those who... veer towards one or other of these extremes, those who experience and tolerate an appropriate degree of realistic anxiety have a greater chance of coping and maximizing their chances of surviving the critical period (2004: 1253).

If such anxiety defences can have catastrophic results at an organizational level, it is also conceivable that they can do so at a grander societal level (Segal, 1987). It may be that collectively the western psyche simply cannot cope with - and therefore 
cannot face up to - the guilt which accompanies lifestyles and modes of social organization that are having such a devastating impact on the planet and long term future of its species and other natural resources. As we have been at pains to point out, there is little disagreement amongst climate scientists, to take one clear example, that the signals of crisis are already there. There is broad consensus that, in Stein's terms, we have already entered the critical period.

This thought brings us back to certain fundamental questions: if we have entered a critical phase of ecocrisis, what might be done by way of steering a successful course between anxiety denial and excessive anxiety? Can anything be done to imagine, anticipate and navigate beyond the other side of catastrophe?

\section{Western Equivalents of the Dream-Vision?}

Western civilization has pursued a trajectory of disenchantment with respect to scientific knowledge and technological advancement (Weber, 1970 [1948]). Similarly, the post-Enlightenment diminution of the influence of Christianity and other religions of the church (Heelas, 2008; Wexler, 1996) has resulted in the predominance of secular ethics (though, clearly, contested by a worldwide Islamic resurgence and evangelistic Christianity in North America, West Africa and elsewhere). Under such circumstances there is little, if any, role for the enchantments of collective dreaming and magic characteristic of indigenous communities. We can no longer conceive of - let alone depend upon - solutions or strategies for dealing with the complex challenges of ecocrisis stemming from shamanic dream-visions. The role of our dream lives and unconscious have, except in the relatively unusual context of psychotherapy, become privatized and inconsequential. Dreams are now more likely to be taken as epiphenomenal byproducts by a scientific psychology increasingly preoccupied with neuroscientific forms of explanation. Even manifestations of the unconscious that may be found in western artworks (visual, literary and performance) are not routinely taken to be of significance. The spiritual value of our aesthetic products have largely become an intimately subjective (rather than collective) affair; confined to a personal relationship with the artwork in question and becoming subsumed within a general syndrome of consumption and ownership.

The resources we are most likely to draw upon in seeking to tackle ecocrisis are far more likely to have rationality at their core. One thinks, for example, of the use of carbon markets and the plethora of proposed geo-engineering solutions ${ }^{8}$ to the problems of climate change, such as, carbon capture and storage, use of sulphur aerosols or technologies to increase the albedo effect, and so forth. Many of these rational proposals have drawn criticism from climate scholars, economists and activists (see, e.g., Reyes, 2009; Reyes and Gilbertson, 2009; Bőhm and Dabhi, 2009). There are also rational scenario planning methods used, for example, by the IPCC (2007). While such approaches certainly entail dreaming in a 'visionary' and (in the case of geo-engineering) 'idealistic' sense their underlying epistemology eschews any symbolic or prescient possibilities of mind. In privileging rational material and social technologies, however, might our disenchanted societies be disregarding resources 
of mind - collective and individual unconscious - which could be mobilized to assist, in whatever modest way, at a moment of crisis? Although conjectural and potentially controversial, we would like to conclude our discussion of the ecocrisis imaginary by considering the possibilities that a symbolic and deliberately non-rational social technology might facilitate a collective seeing of the other side of catastrophe.

\section{Social dreaming and the ecocrisis imaginary}

One exception to the individual focus of western sciences of dream life is Gordon Lawrence's psychoanalytic exploration of social dreaming (Lawrence, 1991, 2003). This is a method in which organisation or community members gather formally in a 'social dreaming matrix' to recount their dreams (i.e., those that occur during sleep not the wishes and hopes sometimes loosely referred to as 'dreams'). In this context dreams express aspects of psychological experience of a world that is shared by all members; bringing a dream to the matrix is a way of holding up a fragment of experience that might connect to others, and in so doing help to make sense of social life.

Like traditional psychoanalysis, social dreaming takes the interpretation of dreams to be a worthwhile and valid means of illuminating experiences that are unconscious and emergent. But unlike psychoanalysis, it proceeds with the telling and interpreting of dreams on behalf of a collective, rather than of an individual. At first glance this might seem to be a short step from accepting that individual dreams pick up and express an individual's experience of social life; in this sense the social dreaming matrix is a means for reintegrating individual dreams in a collective context. But the growing sociological field of 'socio-analysis' (Mant, 1997; Sievers, 2010) suggests something more radical than this: that psychological phenomena, including dreams, are inherently social, generated by the dynamic wholeness of society (or of 'mind'), to which each of us has particular access as if, metaphorically, we are organs of the whole. Starting from this assumption it is evident that the dream-vision granted to any individual is a vision of some aspect of collective life, and not so much a fragment as an outcome of fragmented vision. The 'stuff' of the dream - psychic life - is a contextual wholeness, analogous to the physical world; it is vision that is fragmented by our habitual ego-centeredness. The social dreaming matrix is now cast as a method for integrative visioning; a ritual practice that conjures up a way of seeing that is not available in ordinary individualised waking consciousness, nor in the one-to-one setting of personal therapy.

By concentrating on the dream and not on the person who dreams it, the cultural context of dreaming is addressed. Lawrence (2003: 610) argues that the matrix is a different container for receiving and processing dreams from any other in existence. It 'embodies the principles of connectedness, is the web of mental processes of proto-mental thinking that exists in any social configuration' (Lawrence 2003: 619). Consequently the content of the dreaming alters to take account of its context and becomes social in orientation (Lawrence 2003: 611). Dreaming is the material the mind uses to grow as it processes the events of the day and anticipates the issues it 
has to face in the future. As part of this, the social dreaming matrix inducts participants into the tension between the finite and the infinite, the limits of the known and the unknown. What we know culturally has been 'won from the void and formless infinite' (Milton, 1667; Lawrence, 1991). It is this relation to the infinite that renders us on the edge of a psychic abyss, but one which we habitually venture into through dreams. The social dreaming matrix 'allows participants to have the experience of being in the unknown, to be in doubts, mysteries and uncertainties' (Lawrence, 2003: 620).

Ultimate reality can be thought of as a pool of thoughts awaiting a thinker (Bollas, 1987). From these thoughts the human mind culls elements that form a pattern the human binds together by a name or a number so that they become filled with meaning. Once this happens they become part of the culture of society; part of finite knowledge. 'Culture is brought into existence as human beings transact between the known and unknown, the finite and the infinite' (Lawrence, 2003: 610). In the midst of this transaction, social dreaming facilitates the mental disposition of 'negative capability' (John Keats in Bradley, 1965[1909]; Li, 2009; Symington and Symington, 1996), which allows participants to work at the limits of their comprehension and, as a result, to be available for the apprehension of patterns in the dreaming that lead to new ideas and knowledge (Lawrence, 2003: 611).

Social dreaming appears, therefore, as a method for drawing on resources that are less bound by current cultural norms and assumptions. Hence dreams are rather obviously shameless, and seem to lack respect for cultural authorities (although dreams may be about authority relations, of course). In a social dreaming matrix, transference is towards the dreams themselves, as they have become the expression of authority, of the source of both creative power and containing meaningfulness (Winnicott, 1971). Thus the practice of social dreaming is a ritual for engaging with the pre-acculturated sources of culture, and provides opportunities to read dreams as authoritative statements or oracles. As with any socially sanctioned ritual, participants implicitly share beliefs in the legitimacy of the practice; they may have very different experiences of social life and conflicting political convictions, but must nonetheless engage in the communal practice of the social dreaming matrix. This might be located in established cultural tropes such as Organization Development (OD), founded on practices such as T-groups (Burnes and Cooke, 2012). Like social dreaming, OD has long fostered means for relative strangers (as well as relative intimates) to gather specifically to study and interpret unconscious phenomena as social intelligence. This has extended to policy-oriented engagements with communities (Miller, 1986; Stapely, 2006), and interpretations of social dynamics (Khalleelee and Miller, 1985; Sievers, 2010). Nonetheless, social dreaming is a practice for a group sharing a collective identity, such that personal dreams might conceivably be dreamt 'for us' - even if, as might happen, the dreams themselves pay no heed to such constructed boundaries. It remains to be seen whether, by social dreaming, otherwise disparate individuals might discover or create other salient features of collective identity. Dashtipour (2009) implies as much in his Lacanian-inspired thesis that 'change in identities is less about re-evaluation of social categories/groups at a cognitive level than about a change in the jouissance attached 
to those categories' (2009:325). Further exploration of this suggestion is beyond the scope of this paper, but might be fruitful for subsequent work.

\section{Conclusion}

In the foregoing section we have suggested that social dreaming may offer us a route to discover meanings that are not accessible within normal conscious rationality. This perspective suggests a possible reinterpretation of other contemporary social and political activities; a reinterpretation, moreover, that might be premised on nonanthropocentric ethics. Examples include: economic theories of the commons, in opposition to the marketisation of common goods such as clean air, water, and so forth; experiments with alternative forms of organisations such as co-operatives and collectives; transition towns and local infrastructures that emphasise interdependency, for example in energy generation and distribution. Contemporary spiritualities might likewise be seen as expressions of movements towards psychological states of non-attachment whose literal unselfishness would necessitate embodiment of a non-anthropocentric ethic.

In this article we have taken a story about the fate of the Crow Nation as an allegory for civilizations facing catastrophic collapse. We have identified a number of features of this predicament, specifically: (a) the loss of meaning that results when existentially significant activities are no longer possible; (b) the social function of dreams and their collective interpretation in enabling people to live with imminent catastrophe; and (c) the potential value of dreams as creative sources to inform an embedded ecocrisis imaginary that exceeds the boundaries of individual conscious rationality.

We have suggested that social dreaming is a contemporary homologue of approaches to dreaming and dream cosmologies found in traditional cultures. As such, it possesses significant potential as a practice that, amongst others, might be valuable to citizens of contemporary societies facing ecological and, perhaps, economic and social catastrophe. We acknowledge that the argument for social dreaming above is presented exclusively in theoretical terms. The next stage of our research would be to convene groups willing to participate in social dreaming matrices and to experiment with collective explorations of the ecocrisis imaginary using this method. Our strong suspicion is that social dreaming could have a significant role to play in future educational processes at all levels; to prepare and attune a civilization to understand and accept in deep psycho-physical terms that its entire structure of evaluating the world might soon cease to make sense. 


\section{References}

Adlam, R. and Holyoak, L. (2005) 'Shamanism in the Postmodern World: A Review Essay', Studies in Religion 34: 517-568.

Atkinson, J. M. (1992) 'Shamanism Today', Annual Review of Anthropology 21: 307-330.

Behrensa, A., Giljuma, S., Kovandab, J., and Nizac, S. (2007) 'The Material Basis of The Global Economy: Worldwide Patterns of Natural Resource Extraction and their Implications for Sustainable Resource Use Policies', Ecological Economics 64(2): 444453.

Benedict, R. (1922) 'The Vision in Plains Culture', American Anthropologist 24(1): 123.

Benedict, R. (1923) The Concept of the Guardian Spirit in North America. Menasha, Wisconsin: Collegiate Press

[http://babel.hathitrust.org/cgi/pt?id=mdp.39015046383330, accessed, 30.07.12].

Berkes, F., Colding, J., and Folke, C. (2000) 'Rediscovery of Traditional Ecological Knowledge as Adaptive Management', Ecological Applications 10(5): 1251-1262.

Berkes, F. and Turner, N.J. (2006) 'Knowledge, Learning and the Evolution of Conservation Practice for Social-Ecological System Resilience', Human Ecology 34(4): 479-494.

Bollas, C. (1987) The Shadow of the Object. London: Free Association Books.

Böhm, S. and Dabhi, S. (2009) Upsetting the Offset: The Political Economy of Carbon Markets. London: Mayfly.

Bradley, A.C. (1965/1909) 'The Letters of Keats', in Oxford Lectures on Poetry London: Macmillan.

Burke, K. (1941) 'Four Master Tropes', The Kenyon Review 3(4): 421-438.

Burnes, B. and Cooke, B (2012) 'The past, present and future of organization development: Taking the long view', Human Relations 65(11): 1395-1429

Cajete, G. (2000) Native Science; Natural Laws of Interdependence. Santa Fe, NM: Clear Light Publishers.

Campbell, J. (1973) Myths to Live By. London: Bantham.

Chia, R. C. \& Holt, R. (2011) Strategy Without Design. New York, NY: Cambridge University Press. 
Cohn, N. (1957) The Pursuit of the Millennium: Revolutionary Millenarians and Mystical Anarchists of the Middle Ages. Oxford: Oxford University Press.

Cohn, N. (1995) Cosmos, Chaos and the World to Come: The Ancient Roots of Apocalyptic Faith. New Haven: Yale University Press.

Collier, P. (2010) The Plundered Planet. Oxford: Oxford University Press.

Costanza, R. and Folke, C. (1997) 'Valuing Ecosystem Services with Efficiency, Fairness and Sustainability as Goals', in G. Daily (ed.) Nature's Services: Societal Dependence on Natural Ecosystems, pp.49-70. Washington DC: Island Press.

Costanza, R., Graumlich, L.J. and Steffen, W. (eds)(2007a) Sustainability or Collapse: An Integrated History and Future of Peoples on Earth. Cambridge, MA: MIT Press.

Costanza, R. Graumilch, L.J. and Steffen, W. (2007b) 'Sustainability or Collapse: Lessons from Integrating the History of Humans and the Rest of Nature', in R. Costanza, L.J. Graumlich and W. Steffen (eds) Sustainability or Collapse: An Integrated History and Future of Peoples on Earth, pp.3-18. Cambridge, MA: MIT Press.

Curry, P. (2006) Ecological Ethics. Cambridge: Polity.

Daly, H. and Farley, J. (2004) Ecological Economics: Principles and Applications. Washington, DC: Island Press.

Dashtipour, P. (2009) 'Contested Identities: Using Lacanian Psychoanalysis to Explore and Develop Social Identity Theory', Annual Review of Critical Psychology, 7: 320-337

Devereux, G. (1969 [1951]) Reality and Dream. Psychotherapy of a Plains Indian. New York, International Universities Press.

Diamond, J. (2005) Collapse: How Societies Choose to Fail or Succeed. London: Penguin.

Dietz, T., and Rosa, E. (1997) 'Effects of Population and Affluence on $\mathrm{CO}_{2}$ Emissions', Proceedings of the National Academy of Sciences of the USA 94: 175-179.

Duerr, H. P. (1985) Dreamtime: Concerning the Boundary Between Wilderness and Civilization. Trans, F. D. Goodman, Oxford: Blackwell.

Dyer, G. (2008) Climate Wars: the Fight for Survival as the World Overheats. Toronto: Random House.

Freud, S. (1930 [1961]) Civlization and its Discontents Standard Edition, Vol XXI. London: Hogarth Press and the Institute of Psychoanalysis. 
Gilding, P. (2011) The Great Disruption: How the Climate Crisis Will Transform the Global Economy. London: Bloomsbury

Gilding, P. \& Randers, J. (2010) 'The One Degree War Plan', Journal of Global Responsibility 1(1): 170-188.

Goulet, J-G. (1998) 'Dreams and Visions in Other Lifeworlds', in D.E. Young and J-G. Goulet (eds) Being Changed by Cross-Cultural Encounters, pp.16-38. Toronto: Broadview Press.

Grim, J.A. (2009) 'Indigenous Embodied Knowing: A Study in Crow/Apsaalooke Space, Nature, and the Sacred', in S. Bergmann, P.M. Scott, M. Jansdotter Samuelsson and H. Bedford-Strohm (eds) Nature, Space and the Sacred: Transdisciplinary Perspectives, pp. 203-222. Farnham: Ashgate [http://books.google.com.au/books?hl=en\&lr=\&id=ei5K9p1p4UC\&oi=fnd\&pg=PA203\&dq=Aps\%C3\%A1alooke+dream\&ots=0D1nCURmdB\& sig=vW6tTyzoE1zNd7SS4REPb57pnlU\#v=onepage \&q\&f=false, accessed 04.08.12].

Hallowell, A.I. (1966) 'The Role of Dreams in Ojibwa Culture', in G.E. Von Grunebaum and R. Caillois (eds) The Dream and Human Societies, 267-292. Berkeley: University of California Press.

Hansen, J. (2011) Storms of My Grandchildren : The Truth About the Coming Climate Catastrophe and Our Last Chance to Save Humanity. London: Bloomsbury.

Haslam, S. A., Reicher, S, D., and Platow, M. J. (2008) The New Psychology of Leadership: Identity, Influence and Power. East Sussex: Psychology Press.

Heelas, P. (2008) Spiritualities of Life: New Age Romanticism and Consumptive Capitalism. Oxford: Blackwell.

Heinberg, R. (2005) The Party's Over: Oil, War and the Fate of Industrial Societies. Forest Row: Clairview.

Herrmann, I.T., and Hauschild, M.Z. (2009) 'Effects of Globalisation on Carbon Footprints of Products', CIRP Annals - Manufacturing Technology 58: 13-16.

Intergovernmental Panel on Climate Change (2007) Climate Change 2007: The Physical Science Basis: Summary for Policymakers. IPCC.

[http://www.ipcc.ch/pdf/assessment-report/ar4/wg1/ar4-wg1-spm.pdf, accessed 01.08.12].

Jack, G. and Westwood, R. (2009) International and Cross-Cultural Management Studies: A Postcolonial Reading. Basingstoke: Palgrave Macmillan.

Jackson, T. (2009) Prosperity Without Growth: Economics for a Finite Planet. London: Earthscan. 
Kehoe, A.B. (1992) North American Indians: A Comprehensive Account. Englewood Cliffs, N.J.: Prentice Hall.

Khaleelee, O. and Miller, E. J. (1985) 'Beyond the small group: society as an intelligible field of study'. In M. Pines (ed.) Bion and Group Psychotherapy, pp.354385. London: Tavistock/Routledge.

Lanchester, J. (2007) 'Warmer, Warmer', London Review of Books 29(6): 3-9.

Latour, B. (1993) We Have Never Been Modern. London: Harvard University Press.

Lawrence, W.G. (1991) 'Won From the Void and Formless Infinite: Experiences of Social Dreaming', Free Associations 2(22): 254-266.

Lawrence, W.G. (2003) 'Social Dreaming as Sustained Thinking', Human Relations 56(5): 609-62.

Lear, J. (2006) Radical Hope: Ethics in the Face of Cultural Devastation. Cambridge, MA: Harvard University Press.

Lenton, T. M., Held, H., Kriegler, E., Hall, J. W., Lucht, W., Rahmstorf, S., and Schellnhuber, H. J. (2008) 'Tipping Elements in the Earth's Climate System', Proceedings of the National Academy of Sciences of the United States of America 105(6): 1786-93.

Li, O. (2009) Keats and Negative Capability. London: Continuum International Publishing Group.

Linderman, F. B. (1930) American: the Life Story of a Great Indian, Plenty Coups: Chief of the Crows. New York: John Day

Lomborg, B. (2007) Cool It: The Skeptical Environmentalist's Guide to Global Warming. London: Marshall Cavendish.

Lovelock, J. (2007) The Revenge of Gaia. London: Allen Lane.

McDonald, R. (2005) Rethinking Development: Local Pathways to Global Wellbeing. Antigonish, Nova Scotia: St. Francis Xavier University.

McDonough, W. \& Braungart M. (2002) Cradle to Cradle: Remaking the Way we Make Things New York: North Point Press.

MacArthur, E. (2012) The Circular Economy. Cowes: The Ellen MacArthur Foundation. [www.thecirculareconomy.org, accessed 01.08.12]. 
Mant, A. (1997) Intelligent Leadership. St. Leonards: Allen \& Unwin.

Meadows, D., Randers, J. \& Meadows, D. (2004) Limits to Growth: The 30-year Update. White River Junction, VT: Chelsea Green.

Miller, E. (1986) Conflict and Reconciliation: The Newham Experiment, Tavistock Institue of Human Relations Occasional Paper No. 9. London: Tavistock Institute of Human Relations

Milton, J. (1667) Paradise Lost, Book III, London: Peter Parker of Aldgate, Robert Boulton of Bishopsgate, Martin Walker of Fleet Street.

Monbiot, G. (2006) Heat: How to Stop the Planet Burning. London: Allen Lane.

Myers, N. and Kent, J. (2003) 'New Consumers: The Influence of Affluence on the Environment', Proceedings of the National Academy of Sciences of the United States of America 100(8): 4963-4968.

Naess, A. (1989) Ecology, Community and Lifestyle. Cambridge: Cambridge University Press.

Pick, D. and Roper, L. (2000) 'Psychoanalysis, Dreams, History: an Interview with Hanna Segal', History Workshop Journal Spring: 161-70.

Raskin, P., Banuri, T., Gallopin, G., Gutman, P., Hammond, A., Kates, R., \& Swart, R. (2002) Great Transition. The Promise and Lure of the Times Ahead. A Report of the Global Scenario Group, Boston, MA: Stockolm Environment Institute [http://www.tellus.org/Documents/Great_Transitions.pdf, accessed 01.08.12].

Raupach, M. R., Marland, G., Ciais, P., Le Quéré, C., Canadell, J.G., Klepper, G. and Field, C.B. (2007) 'Global and Regional Drivers of Accelerating $\mathrm{CO}_{2}$ Emissions', Proceedings of the National Academy of Sciences of the United States of America 104(24): 10288-10293.

Reyes, O. (2009) 'Climate Technologies: a Leap Into the Unknown', Transnational Institute [http://www.tni.org/article/climate-technologies-leap-unknown, accessed 01.08.12].

Reyes, O. and Gilbertson, T. (2009) Carbon Trading: How it Works and Why it Fails. Uppsala: Dag Hammarskjöld Foundation.

Ridley, M. (2011) The Rational Optimist: How Prosperity Evolves. London: Fourth Estate.

Rockström, J. Steffen, W., Noone, K., Persson, Å., Chapin, F. S. III, Lambin, E.F., Lenton, T. M., Scheffer,M., Folke, C. Schellnhuber, H.J., Nykvist, B., De Wit, C. A. , Hughes, T., van der Leeuw, S., Rodhe, H., Sörlin, S., Snyder, P.K., Costanza, R., Svedin, 
U., Falkenmark, M., Karlberg, L., Corell, R. W., Fabry, V. J., Hansen, J., Walker, B., Liverman, D., Richardson, K., Crutzen, P. and Foley, J. (2009) 'A safe operating space for humanity', Nature, 461: 472-5

Schein, E. (2004) Organizational Culture and Leadership. San Fransisco: Jossey Bass.

Segal, H. (1987) 'Silence is the Real Crime', International Review of Psychoanalysis 14: 3-12.

Sievers, B. (2010) 'Beneath the Financial Crisis', in H. Brunning and M. Perini (eds) The Psychoanalytic Perspective on the Turbulent World: 117-37. London: Karnac.

Smith, S.L. (2000) Reimagining Indians: Native Americans through Anglo eyes, 1880 1940. Oxford: Oxford University Press.

Stapley, L.F. (2006) 'A large system intervention: the influence of organisational culture'. In L. J. Gould, L. F. Stapley and M. Stein (eds) The Systems Psychodynamics of Organizations: Integrating the Group Relations Approach, Psychoanalytic and Open Systems Perspectives: 157-174. London: Karnac Books.

Stahel, W. (2010) The Performance Economy (2 ${ }^{\text {nd }}$ edition). London: Palgrave MacMillan.

Stein, M. (2004) 'The Critical Period of Disasters: Insights from Sense-making and Psychoanalytic Theory', Human Relations 57(10): 1243-61.

Stern, N. (2007) The Economics of Climate Change: The Stern Review. London: HM Treasury.

Sylvan, R. and Bennett, D. (1994) The Greening of Ethics. Cambridge: White Horse Press.

Symington, N. and Symington, J. (1996) The Clinical Thinking of Wilfred Bion. London: Routledge.

Tajfel, H. and Turner, J. C. (1986) 'The Social Identity Theory of Inter-group Behavior', in S. Worchel and L. W. Austin (eds), Psychology of Intergroup Relations: 7-24. Chicago: Nelson-Hall.

UNEP (United Nations Environment Programme) (2011) Towards a Green Economy: Pathways to Sustainable Development and Poverty Eradication Nairobi: UNEP. [http://www.unep.org/greeneconomy/greeneconomyreport/tabid/29846/default.as px, accessed 01.08.12].

Urry, J. (2008) 'Climate Change, Travel and Complex Futures', British Journal of Sociology 59(2): 261-79. 
Uzzi, B. (1997) 'Social Structure and Competition in Inter-firm Networks: the Paradox of Embededdedness', Administrative Science Quarterly 42: 35-67.

Versluis, A. (1993) Native American Traditions. Shaftesbury: Element.

Vizenor, G. (1998) Fugitive Poses: Native American Indian Scenes of Absence and Presence. Lincoln: University of Nebraska Press.

Warrior, R. A. (1995) Tribal Secrets: Recovering American Indian Intellectual Traditions. Minneapolis: University of Minnesota Press.

Weber, M. (1970 [1948]) From Max Weber: Essays in Sociology. Trans Hans Gerth and C. Wright Mills, London: Routledge \& Kegan Paul.

Weick, K. (1979) The social psychology of organizing, Reading, MA: Addison-Wesley

Weick, K.E. (1993) 'The Collapse of Sensemaking in Organizations: The Mann Gulch Disaster', Administrative Science Quarterly 38: 628-52.

Wexler, P. (1996) Holy Sparks: Social Theory, Education and Religion. New York: St Martin's Press.

Whiteman, G. and Cooper, W. H. (2000) 'Ecological Embeddedness', Academy of Management Journal 43(6): 1265-82.

Whiteman, G. and Cooper, W.H. (2011) 'Ecological Sensemaking', Academy of Management Journal 54 (5): 889-911.

Whiteman, G., Walker, B. \& Perego, P. (2012) 'Planetary Boundaries: Ecological Foundations for Corporate Sustainability' Journal of Management Studies, 'Accepted Article', doi: 10.1111/j.1467-6486.2012.01073.x

Winnicott, D.W. (1971) Playing and Reality. London: Tavistock Publications.

\section{End Notes}

\footnotetext{
${ }^{1}$ Jared Diamond, for example, adopts the use of metaphor to explore relationships between the demise of the Easter Islanders and contemporary threats to humanity: 'The parallels between Easter Island and the whole modern world are chillingly obvious. Thanks to globalization, international trade, jet planes, and the Internet, all countries on Earth today share resources and affect each other, just as did Easter's dozen clans. Polynesian Easter Island was as isolated in the Pacific Ocean as the Earth is today in space' (Diamond, 2005: 119).

2 The name Plenty Coups is a contemporaneous white trapper argot translation of the Crow word Alaxchiiaahush, meaning 'Many Achievements' (Lear, 2006: 20).

${ }^{3}$ See, for example, Ridley, 2011, for a rationalist rebuttal of the pessimism of ecocrisis critiques. For our part, we are entirely sympathetic to the magical and spiritual realities of dream worlds whether considered in traditional or modern contexts.
} 
${ }^{4}$ The role of dreams and visions in indigenous American lifeworlds has been explored extensively in the anthropological literature. Historical and more recent examples include: Benedict $(1922,1923)$, Devereux, (1969 [1951]), Goulet (1998), Hallowell (1966), Kehoe (1992), Versluis (1993). Grim (2009) offers a salient account of the embodied nature of Apsáalooke spiritual nature in relation to dream and ritual.

${ }^{5}$ See also Pick and Roper (2000) for Hanna Segal's discussion of how, in Freudian terms, individual dreams may be culturally mediated.

${ }^{6}$ Trade in 'buffalo robes' increased from 2,600 in 1830 to 110,000 by 1848 (Lear, 2006: 73).

${ }^{7}$ There is, of course, a long history of instructions on 'how to confront catastrophe'. Cohn (1995) argues that until about $1500 \mathrm{BC}$ natural and military disasters were understood to exist within an essentially ordered cosmos established and maintained by the Gods (notwithstanding their disturbance-inducing squabbles). The prophet Zoroaster, sometime between 1500 and $1200 \mathrm{BC}$, is credited with a radical reinterpretation of the warring Gods. He suggested that at some time the conflict would be resolved, evil would be swept away and a purified order of unalloyed goodness would be established. Thus catastrophe was re-conceived as a veil, on the other side of which lies a world of perfect harmony. A tradition of apocalyptic literature ('apocalypse' in Greek is ároká $\lambda \cup \psi ı$ apokálypsis; 'lifting of the veil' or 'revelation') conveys in nightmarish images the tribulations by which we shall be made fit for life on the other side, and advises on how to prepare for the end of days. Faced with impending disaster, ideologues and prophets beseech fellow citizens to reform, and to acts of contrition or - if the situation is hopeless - anarchic abandon (Cohn, 1957). The belief that a perfect life will be found on the other side of death was picked up in biblical times by, amongst others, the Jewish sect of Jesus, and thence into the eschatological underpinnings of Christianity and modernity. Cohn argues that it was the basis of Nazi doctrines of the 'volk', justifying eradication of 'impure' Jews, homosexuals, disabled people and so forth. The same might be said of utopian versions of Communism, made possible by cultural revolution; both ideologies located their utopias after of a deluge of destruction.

${ }^{8}$ It strikes us that some of the proposed geo-engineering solutions may find inspiration from an aesthetic source, that is, the science fiction genre. Indeed, we speculate that science fiction has been important in shaping the unconscious apocalyptic motif which informs a climate change catastrophe imaginary. However, this sub-genre of fiction is itself in large measure the symbolic working through of a collective, if ambiguous and problematic, preoccupation with rationality. 